Journal of Extension Education

Vol. 28 No. 4, 2016

DOI:https: / / doi.org/10.26725/JEE.2016.4.28.5753-5759

\title{
Attitude of Farmers towards Kisan Call Centres
}

\author{
Shely Mary Koshy ${ }^{1}$ and N. Kishore Kumar ${ }^{2}$
}

\begin{abstract}
The present study was conducted to measure the attitude of farmers in Kerala, India towards Kisan Call Centre (KCC). Kisan Call Centre provides free agricultural advisory services to every citizen involved in agriculture through a toll free number. One hundred and fifty farmers who have utilized the Kisan Call Centre service were selected from the database of KCC. The results showed that the respondents had moderately favourable attitude towards KCC followed by highly favourable attitude. The variables digital divide, temporal awareness on KCC, satisfaction towards KCC and utilization of KCC were found to have a positive correlation with the attitude of respondents towards KCC.
\end{abstract}

Keywords: Attitude, Kisan Call Centre, Agricultural advisory service, Kerala.

\section{INTRODUCTION}

India is home to 1.21 billion population where over 70 percent of rural households depend on agriculture. There are reports showing that the population dependent on agriculture grew 50 percent from a period of 19802011. This growth definitely needs to be accompanied by profitable and economically viable technologies and methods that would help to prosper and attract more and more farmers into farming.

ICT (Information and communication technology) is bringing the world closer at an astonishingly faster rate, enabling people in the most remote places in earth to communicate with each other within seconds. ICT encompasses all those technologies that enable the handling of information and facilitate different forms of communication among human actors, between human beings and electronic system (Acharya et al.,2013). Nowadays the use of ICT is increasing and it plays an important role in developing agriculture and also helps in socio economic development (Farooqi et al., 2002).

The population in India is increasing day by day. The wide gap between farmers and the extension agents restricts the extension system from reaching the farmers to provide service.

1. Ph.D. Scholar and 2. Professor, Department of Agricultural Extension, College of Agriculture, Kerala Agricultural University, Vellayani - 695 522, Kerala 
Moreover the farmers are geographically scattered. This is more pronounced in a state like Kerala where people live in isolated homesteads. Due to this, face to face dissemination of information would be costly. Another problem is that the extension agents find it difficult to reach the targeted audience. ICTs, especially mobile phones can help to communicate to those who depend on the traditional communication sources. There are more than 43 Mobile based extension services pertaining to agriculture provided by public, private and both private and public partnership mode. Some of these services are paid and some of the services are free of cost. One among the services that is free of cost and which is provided all over India is the Kisan Call Centre (KCC). 'Kisan' is the Hindi equivalent of farmer.

The Kisan Call Centre was launched on twenty first of January, 2004 by the Department of Agriculture \& Cooperation (DAC), Ministry of Agriculture \& Farmers Welfare, Govt. of India to provide free tele agricultural advisory services to the farming community by exploiting the tele communication facility. The service can be availed from 6 am to 10 pm throughout the week by the farming community in their respective local language throughout the country through the toll free number 1800-180-1551. The Kisan Call Centre consists of three levels namely Level-I, where the calls from the farmers are directly connected to Level I, handled by agricultural graduates in the local language who are in a position to answer the majority of the queries of the farmers. Level-II is the Subject Matter Specialists from KVK and Krishi Bhavan. When the queries cannot be solved by the Level I agents the calls are transferred to Level II. Finally the Level-III is operated by the Subject Matter Specialists (SMS) from the nodal office.

Attitude is the positive or negative feeling associated with some psychological object. An attitude towards an item depends upon the information, knowledge and the emotional perception a person towards it. Since the inception of KCC, very few studies have been conducted so far to understand the attitude of farmers towards KCC and hence the study was carried out.

\section{METHODOLOGY}

The study was conducted during October 2015 to January 2016. One hundred and fifty respondents were selected purposefully from the database of Kisan Call Centre in order to ensure that respondents from all over Kerala were included. The data were collected with the help of a questionnaire. An attitude scale which would measure the attitude of farmers towards $\mathrm{KCC}$ was constructed. The attitude scale consisted of 15 positive and eight negative statements. The reliability of the scale 
was calculated using Spearman Brown formula and was found to be 0.969 which showed the scale was highly reliable. The final scale consisting of 23 statements was administered to the respondents and were asked to mark their response on a five point continuum as strongly agree, agree, undecided, disagree and strongly disagree with scores of $5,4,3,2,1$ respectively for positive statements and the scoring was reversed in case of negative statements. The statement score was obtained by multiplying the scale value for a particular statement with the score assigned by the respondent and the individual score was calculated by summing all the statement score with respect to a particular individual. The respondents were classified into three groups based on their scores as less favourable (if the score obtained was less than 'Mean- Standard Deviation'), moderately favourable (if the score obtainedwas greater than 'Mean-Standard Deviation and less than Mean+ Standard Deviation') and highly favourable (if the score obtained was greater than 'Mean + Standard Deviation').

\section{FINDINGS AND DISCUSSION}

The study revealed that $52 \%$ of the respondents using $\mathrm{KCC}$ belonged to the age category of 36-55 years of age. Majority of the respondents were male. Forty nine percent of the respondents had high school level education. Majority of the respondents were involved in other occupations either in Government or private sector along with agriculture. Forty three percent of the respondents were found to earn an income of more than Rs 50,000/- annually. The respondents' contact with various extension agencies was found to be medium. The innovativeness of the respondents was found to be low as majority (59\%) of the farmers preferred to take their own time before accepting an innovation. The experience in internet use was very less among the respondents. Only 13 percent of respondents had more than 6 years of experience in internet usage whereas sixty percentage of the respondents did not have any experience in internet usage. The respondents had medium level of information source utilization. Sixty four per cent farmers was found to have more than three years of temporal awareness on KCC and $52 \%$ of the farmers had utilized the service more than six times. The major constraint faced by the respondents in using $\mathrm{KCC}$ was lack of good connectivity.

To group the respondents based on their attitude towards KCC, the interval of standard deviation from mean was used. The attitude of $15 \%(n=24)$ of respondents towards KCC was less favourable. In addition, 26\% ( $\mathrm{n}=39$ ) of respondents had more favourable attitude and $58 \%$ of them $(\mathrm{n}=87)$ had favourable attitude. 
Table 1.

Ranking of Statements

\begin{tabular}{|c|l|c|c|c|c|}
\hline $\begin{array}{c}\text { S1. } \\
\text { No. }\end{array}$ & Statements & Mean & $\begin{array}{c}\text { Standard } \\
\text { Deviation }\end{array}$ & CV & Rank \\
\hline 1. & $\begin{array}{l}\text { Solutions provided through KCC are } \\
\text { very helpful }\end{array}$ & 4.000 & 0.955 & 0.892 & I \\
\hline 2. & $\begin{array}{l}\text { The centre provides solutions for only } \\
\text { regular farm related problems* }\end{array}$ & 3.833 & 1.172 & 0.895 & II \\
\hline 3. & $\begin{array}{l}\text { KCC extension services avoid the } \\
\text { personal extension contact* }\end{array}$ & 3.293 & 1.090 & 0.898 & III \\
\hline 4 & $\begin{array}{l}\text { KCC extension service is faster when } \\
\text { compared to the traditional extension } \\
\text { services }\end{array}$ & 2.960 & 1.080 & 0.907 & IV \\
\hline 5. & $\begin{array}{l}\text { KCC based extension services are } \\
\text { alternative to the present extension } \\
\text { system }\end{array}$ & 2.747 & 1.050 & 0.981 & V \\
\hline 6. & $\begin{array}{l}\text { Work assignments are not fully } \\
\text { explained in KCC by the officials* }\end{array}$ & 3.627 & 0.994 & 1.096 & VI \\
\hline 7. & $\begin{array}{l}\text { KCC services is a distant dream for } \\
\text { resource poor farmers* }\end{array}$ & 3.680 & 0.951 & 1.104 & VII \\
\hline 8. & KCC saves farmers' time & 3.293 & 1.288 & 1.138 & VIII \\
\hline 9. & $\begin{array}{l}\text { Illiteracy will not deter farmers from } \\
\text { availing KCC services }\end{array}$ & 3.680 & 1.070 & 1.148 & IX \\
\hline 10. & $\begin{array}{l}\text { All kinds of information exchange are } \\
\text { possible through KCC }\end{array}$ & 3.707 & 1.283 & 1.158 & X \\
\hline 11. & $\begin{array}{l}\text { Phone-in-line with scientists gives first- } \\
\text { hand information about queries }\end{array}$ & 3.427 & 1.131 & 1.179 & XI \\
\hline 12. & $\begin{array}{l}\text { Recommendations provided through } \\
\text { telephone is clear and easy to } \\
\text { understand }\end{array}$ & 3.567 & 1.266 & 1.181 & XII \\
\hline
\end{tabular}




\begin{tabular}{|c|l|c|c|c|c|}
\hline 13. & $\begin{array}{l}\text { The farmers following KCC } \\
\text { recommendations get positive results }\end{array}$ & 3.593 & 1.280 & 1.183 & XIII \\
\hline 14. & $\begin{array}{l}\text { KCC provides new methods for solving } \\
\text { field problems }\end{array}$ & 3.880 & 0.948 & 1.207 & XIV \\
\hline 15. & $\begin{array}{l}\text { At times, KCC is not good at all in terms } \\
\text { of dairying* }\end{array}$ & 3.820 & 1.075 & 1.266 & XV \\
\hline 16. & $\begin{array}{l}\text { KCC agents often fail to comprehend the } \\
\text { queries* }\end{array}$ & 3.473 & 1.091 & 1.271 & XVI \\
\hline 17. & $\begin{array}{l}\text { KCC extension services had been } \\
\text { helpful in building a skilled and } \\
\text { knowledge community }\end{array}$ & 2.660 & 1.054 & 1.366 & XVII \\
\hline 18. & $\begin{array}{l}\text { KCC can never replace traditional } \\
\text { method of extension service* }\end{array}$ & 2.740 & 1.089 & 1.490 & XVIII \\
\hline 19. & $\begin{array}{l}\text { KCC is one of the potential tools of ICT } \\
\text { to reach needy farmers }\end{array}$ & 3.387 & 1.225 & 1.592 & XIX \\
\hline 20. & $\begin{array}{l}\text { The benefits received from KCC are as } \\
\text { good as most other organizations offer } \\
\text { to farmers }\end{array}$ & 3.893 & 0.949 & 1.628 & XX \\
\hline 21. & $\begin{array}{l}\text { KCC provides fair amount of information } \\
\text { for the queries farmers ask }\end{array}$ & 3.753 & 1.129 & 1.634 & XXI \\
\hline 23. & $\begin{array}{l}\text { For instant information KCC is always } \\
\text { used }\end{array}$ & 3.447 & 1.102 & 1.647 & XXII \\
\hline input shops* & 2.38 & 1.293 & 1.662 & XXIII \\
\hline
\end{tabular}

*- Negative statements

Data in Table 1 show that the statement namely, the solutions provided through KCC is very helpful was ranked first. This might be because of the benefits received by the respondents of using $\mathrm{KCC}$. 
Table 2.

Correlation of attitude towards KCC with other variables

\begin{tabular}{|c|l|c|}
\hline S1. No. & \multicolumn{1}{|c|}{ Independent variables } & Attitude towards KCC \\
\hline 1. & Age & -0.133 \\
\hline 2. & Education & 0.012 \\
\hline 3. & Income & -0.057 \\
\hline 4 & Occupation & -0.076 \\
\hline 5. & Extension Agency Contact & -0.092 \\
\hline 6. & Innovativeness & -0.057 \\
\hline 7. & Digital divide & $0.233^{* *}$ \\
\hline 8. & Experience in internet use & -0.120 \\
\hline 9. & Information source utilization & 0.045 \\
\hline 10. & Temporal awareness on KCC & $0.275^{* *}$ \\
\hline 11. & Satisfaction & $0.293^{* *}$ \\
\hline 12. & Utilization of KCC & $0.242^{* *}$ \\
\hline 13. & Constraints & $-0.364^{* *}$ \\
\hline
\end{tabular}

It could be inferred from the table that digital divide, temporal awareness on $\mathrm{KCC}$, satisfaction towards $\mathrm{KCC}$ and utilization of $\mathrm{KCC}$ were found to be positively correlated with attitude towards KCC. A negative correlation was found between the constraints in using KCC and attitude towards KCC. When the digital divide decreases, the accessibility and availability of other ICT tools for information utilization reduces. In such a situation, respondents tend to depend on those ICT tools that more accessible. The temporal awareness and utilization of $\mathrm{KCC}$ was also found to have positive relationship with the attitude towards KCC. When the temporal awareness increases the utilization also increases and an increased utilization might be due to the satisfaction derived in utilizing the service.

\section{CONCLUSION}

The results of the study revealed that the respondents were found to have favourable attitude towards KCC. Factors like easiness to access the call centre, time saving factor, quick response 
and its advantages over the traditional extension system could have aided its favorableness. The factors temporal awareness of KCC, utilization of KCC, satisfaction with $\mathrm{KCC}$ and the digital divide were found to positively influence the attitude of respondents using $\mathrm{KCC}$ and the constraints in using the $\mathrm{KCC}$ was found to negatively influence the attitude of respondents towards KCC. In this fast moving world, the farmers also are seeking for services which are quick and easy to access and Kisan Call Centre can be the answer for this. The concerned authorities may make efforts to resolve the issues faced by the respondents in using the KCC.

\section{REFERENCES}

Acharya, H. S., Dutta, S. R., \& Bhoi, R. K. (2013). Information technology and its role to manage sustainable finance. International Journal of Advanced Research Management and Social Science, 2 (2), 144-149.

Farooqi, M. S., Singh, N. \& Islam, S. (2002). Information technology potential and prospects. Agricultural Extension Review, 14 (5), 25-27.

Koshy, S.M. \& Kishore Kumar, N. (2015). A scale to measure the attitude of farmers towards Kisan Call Centre. Journal of Extension Education, 27(4) 